RAFAŁ MICHALCZUK

Instytut Stosunków Międzynarodowych UMK

Katedra Filologii Germańskiej UMK

\title{
„Długie pożegnanie z Jugosławią". Wojna Petera Handkego z literaturą, polityką i mediami
}

\begin{abstract}
A ustriacki pisarz Peter Handke (ur. w 1942 roku w Griffen) debiutował Aprowokacyjnym wystąpieniem na spotkaniu Grupy 47 oraz inscenizacją sztuki Powymyślana publiczność (Die Publikumsbeschimpfung). Twórczość literacka Handkego od początku była ukierunkowana na wysublimowaną prowokację. Drugim, nie mniej ważnym, komponentem jego działalności pisarskiej stało się literackie zaangażowanie polityczne. Handke wpisuje się tutaj w szerszy nurt literatury politycznej. Wraz z zabraniem przez niego głosu w międzynarodowej dyskusji na temat rozpadu federacji Jugosławii, w 1991 roku, literackie zaangażowanie polityczne Handkego osiągnęło swoistego rodzaju apogeum. Z wydaniem na łamach niemieckiego dziennika „Süddeutsche Zeitung" w roku 1991 eseju Pożegnanie z dziewiatym krajem ${ }^{1}$ (Der Abschied vom Neunten Land) pisarz rozpoczął istną wojnę z literaturą, polityką i mediami, która wraz z eskalacją konfliktu w Jugosławii przybierała coraz bardziej na sile i żywotności. Tytuł niniejszego artykułu odwołuje się do wywiadu z samym Peterem Handkem, który ukazał się pod oryginalnym niemieckim tytułem Der lange Abschied von Jugoslawien na łamach gazety „Neue Zürcher Zeitung" 17 czerwca 2006 roku.
\end{abstract}

Poza tekstami Petera Handkego, które zostały przetłumaczone i opublikowane w języku polskim, wszystkie pozostałe cytaty i tytuły utworów opierają się na własnym tłumaczeniu autora artykułu. 


\section{Handke - skandalista?}

W roku 1996 Peter Handke aktywnie włączył się w niemiecką i międzynarodową debatę o tematyce bałkańskiej: jego publikacje ingerowały bezpośrednio w spór dotyczący wojen wybuchających w momencie rozpadu Federacji Jugosłowiańskiej oraz w czasie niezwykłego nasilenia medialnego. Handke stał się obiektem prawdziwego politycznego oburzenia otoczonego aurą nie tyle prowokacji, co skandalu, który „,przeszył na wskroś cały pejzaż medialny". Batalia na łamach gazet, liczne publiczne wypowiedzi ważnych osobistości, często również niewybredne inwektywy oraz polityczne werdykty towarzyszyły literackiemu/politycznemu zaangażowaniu Petera Handkego w konflikt wokół rozpadu wielonarodowościowego państwa Jugosławii' ${ }^{2}$.

Handke, z jednej strony, bardzo sceptycznie i w wysoce krytycznych słowach wyrażał się w tej debacie o relacjonowaniu wydarzeń z obszaru konfliktu oraz wskazywał na obraz zachodnich mediów, z drugiej strony, wypowiadał się na temat konkretnej roli podejmowanych przez państwa (zachodnio-)europejskie działań związanych z konfliktem. I tutaj, zdaje się, pisarz dotknął dwóch płaszczyzn poważnego konfliktu: wojny z polityką i mediami. W szczególności krytykował rzekomą „konieczność” oraz brak legitymacji działań polityczno-militarnych podjętych przez państwa zachodnie. Ponadto, zarzucał mediom zbyt jednostronne przedstawianie konfliktu w prasie i w telewizji według czarno-białego schematu ${ }^{3}$. Krytykę Handke kierował w ten sposób zarówno przeciwko medialnej metodzie przedstawiania rzeczywistości, jak i pewnej - wypaczonej według niego - logice polityki państw zachodnich $^{4}$.

\section{Są zaangażowani ludzie, ale nie ma zaangażowanych pisarzy}

Intrygujące są poglądy Handkego, które sformułował wobec „zaangażowania politycznego literatury" w czasach studenckich. W eseju Literatura jest romantyczna dochodzi do wniosku: „Są zaangażowani ludzie, ale nie ma zaangażowanych pisarzy"s. Według niego zaangażowana literatura nie istnieje. To pojęcie jest sprzecznością samą w sobie. Są zaangażowani ludzie,

Por. A. Lindner, Peter Handke, Jugoslawien und das Problem der strukturellen Gewalt. Literaturwissenschaft und politische Theorie, Berlin 2007, s. 16.

Por. tamże, s. 16.

Por. tamże, s. 16-17.

P. Handke, Die Literatur ist romantisch, w: tenże, Ich bin ein Bewohner des Elfenbeinturms, Frankfurt am Main 1972, s. 43. 
ale nie ma zaangażowanych pisarzy. Pojęcie „zaangażowanie” jest polityczne. Można je zastosować wobec politycznych „pisarzy”, którzy jednak nie są pisarzami w tym sensie, jaki nas tutaj interesuje, lecz są politykami, którzy piszą to, co chcą powiedzieć". Wobec własnego zaangażowania Handkego w konflikt polityczny, zdaje się, że dawne poglądy zeszły na dalszy plan.

\section{Literackie zapowiedzi wielkiej burzy}

Aby zrozumieć chociaż w części gwałtowność wystąpienia Handkego w obronie własnych koncepcji polityczno-literackich, należy sobie uświadomić, jaką rolę pełniła Jugosławia w twórczości pisarza. Handke w eseju Pożegnanie z dziewiatym krajem przyznaje, że nie chce zgrywać się jako „Słoweniec"', ale niewątpliwie tożsamość literata jest wielopłaszczyznowa i łączy się również ze Słowenią, która zajmuje w jego twórczości szczególną rolę, a jest przez niego pojmowana jako integralna część Jugosławii.

Sam o sobie Handke mówi, że urodził się na wsi w Karyntii (południowa Austria), gdzie w czasie drugiej wojny światowej „większość”, autor poprawia się na „całość ludności”, była austriacko-słoweńska. Mówiono w odpowiednim „dialekcie”, czyli językiem słoweńskim. Matka pisarza, według jego własnych słów, znajdowała się pod wpływem jego najstarszego brata, który w jugosłowiańsko-słoweńskim Mariborze studiował sadownictwo drzew owocowych. Czuła się ona więc w zasadzie przynależna do mniejszości słoweńskiej w Karyntii. Ojciec pisarza był niemieckim żołnierzem, więc młody autor posługiwał się językiem niemieckim. W czasach swojego dzieciństwa w Berlinie Wschodnim opisuje, że język słoweński i słoweńskie korzenie coraz bardziej traciły dla niego na znaczeniu. Autorowi jako dziecku wielkiego niemieckiego miasta słoweńskie dźwięki sprawiały wręcz fizyczny ból ${ }^{8}$.

\section{Nawet nie „Pół-Słoweńcem”}

Zmieniło się to dopiero $\mathrm{z}$ biegiem czasu, gdy przodkowie zaczęli wrażliwemu pisarzowi przekazywać, opowiadać obrazy ${ }^{9}$. Według słów autora: „«Słoweńcem» nie stałem się jednak nigdy, nawet nie «Pół-Słoweńcem», choć ten język z upływem czasu umiem już jako tako odczytać; jeśli dziś widzę siebie w czymś takim jak lud (naród), to w ludzie złożonym z nikogo - co

Tamże, s. 43.

P. Handke, Abschied des Träumers vom Neunten Land, w: tenże, Abschied des Träumers vom Neunten Land. Eine winterliche Reise zu den Flüssen Donau, Save, Morawa und Drina oder Gerechtigkeit für Serbien. Sommerlicher Nachtrag zu einer winterlichen Reise, Frankfurt am Main 1998, s. 7.

8 Por. tamże, s. 7-8.

9 Por. tamże, s. 8-9. 
tymczasowo może dawać pewną ulgę, ale na długi czas jest to przekleństwem"10.

A mimo to, pisarz przyznaje, że nigdzie na świecie jako osoba obca nie czuł się bardziej w domu (zu Hause) niż właśnie w Słowenii. Przez długi czas wydawało mu się, że znalazł tam pewne poczucie stateczności, trwania - inaczej niż w jego „oszukańczym dzieciństwie” w Berlinie Wschodnim ${ }^{11}$. Na pytanie: „W domu w Słowenii, w Jugosławii?” odpowiada: „W rzeczywistości”. Handke widzi Słowenię oraz nierozłącznie z nią również Jugosławię jako przeciwieństwo opisanej przez Hofmannstahla nierzeczywistości ${ }^{12}$.

W swoim „eseju autobiograficznym”, który ukazał się w zbiorze Ich bin ein Bewohner des Elfenbeinturms Handke odnosi się do języków: „Nauczono mnie gardzić jednymi językami, a kochać drugie języki. Jednej z mniejszości u nas, która od dziecka uczyła się słowiańskiego języka, radziliśmy, żeby poszła do kraju, gdzie większość mówi w tym języku"13. Oczywiście chodzi w tym przypadku właśnie o język słoweński.

\section{Powtórka z życia?}

W utworze Powtórka (Die Wiederholung) Handke przemawia ustami swojego protagonisty. Dla niego biały chleb oznacza Jugosławię. Wiąże się ona z pamięcią o zaginionym bracie, który w Mariborze uprawiał sad ${ }^{14}$. Poza tym, Handke widzi Słowenię/Jugosławię w przeciwieństwie do swojej tzw. ojczyzny; wyraża to jego protagonista w Powtórce.

Filip Kobal zadaje sobie pytanie, dlaczego na podupadłym terenie przemysłowym w Jugosławii, utrzymywanym jakby przez niewidzialną rękę, zrobili na nim tak niespotykane dotąd wrażenie pracownicy, w ogóle ludzie? Nie było to spowodowane zupełnie innym ustrojem i systemem społecznym (czytaj: komunizmem w wydaniu jugosłowiańskim) ani samym pobytem zagranicą, raczej była to dla niego pewność, że w końcu, po już niemal 20 latach w „bezmiejscowym państwie” (ortloser Staat), mroźnym, nieprzyjaznym, ludożerczym tworze, teraz znalazł się przy granicy państwa, które inaczej niż „tak zwany kraj urodzenia” (sogenannter Geburtsstaat), nie stawiał wobec Handkego żadnych wymagań: nie musiał mu on służyć swoją obecnością jako uczeń zobowiązany do służby wojskowej lub zastępczej. Przeciwnie, to ten kraj miał wobec niego zobowiązanie, który jako należący do jego przodków

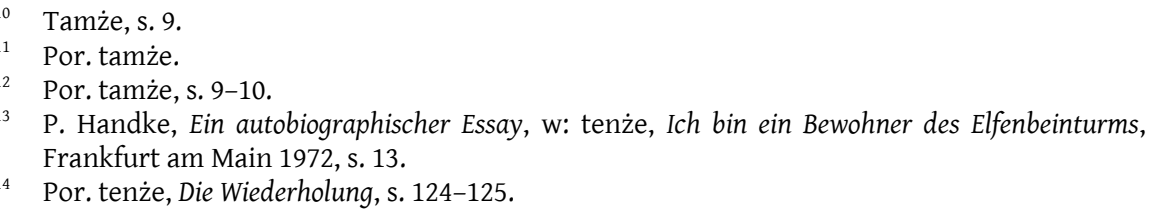


był - mimo całej obcości - również jego własnym krajem ${ }^{15}$. „W końcu byłem bezpaństwowcem, zamiast być przez cały czas obecnym, mogłem być bez obaw nieobecny, w końcu czułem, choć wokół nie pojawiał się nikt, że jestem wśród swoich"16.

\section{Mitteleuropa}

Już po całej „burzy” o usamodzielnienie się Słowenii, dużo później, bowiem w 2006 roku Handke odpowiada na pytanie czy Słowenia, „dziewiąty kraj" nie jest dla niego ojcowizną. Znaczącym momentem, w którym przestał on rozumieć postępowanie Słowenii, była chwila, gdy słoweńscy pisarze trzy, cztery lata przed wojną zaczęli wypowiadać się publicznie, że już nie są "Jugosłowianami, lecz mieszkańcami środkowej Europy (Mitteleuropa)"17. Intelektualiści zaczęli wtenczas postulować, aby wznieść w Chorwacji „dwupiętrowy mur przeciwko Serbom, Macedończykom, Muzułmanom oraz Albańczykom"18. Handke z takim stanowiskiem nie mógł się pogodzić i oświadczył: „w chwili, gdy z regionu robi się ideologię, to wszystko we mnie się burzy. Dlatego pożegnałem się ze Słowenią. I z jej pisarzami. Oni wyrządzili sporo zła. Może przesadzam. Ja bym tego nigdy nie zrobił: użyć kraj jako maczugę, krainę, którą się kocha, miejsce z którego pochodzi rytm języka, wykorzystać do tego, aby inne narody przedstawiać w złym świetle"19.

W rozmowie z Peterem Handke Jože Horvat odnosi się do wypowiedzi pisarza, że Mitteleuropa jest pojęciem meteorologicznym. Ten odpowiada, wyjaśniając swój wrogi stosunek do tej koncepcji. Według niego, regionalizm jest dosyć dobrym zjawiskiem, lecz współpraca Alpy-Adriatyk nie podoba mu się wcale. Według pisarza jest ona wyłącznie zasłoną dymną dla austriackiego nacjonalizmu. Prawdziwy regionalizm powinien opierać się na równorzędnym partnerstwie równych stron ${ }^{20}$. „Dążenie do Mitteleuropy wydaje mi się zupełnie niemożliwe, bowiem w przeszłości stało się tu z narodami, które żyły przecież w dużej mierze w jednym wspólnym państwie, tyle złego, że nie mogą one żyć wspólnie"21.

Por. tamże, s. 118-119.

Tamże, s. 119.

Der lange Abschied von Jugoslawien - wywiad z Peterem Handke zob. „Neue Zürcher Zeitung” z dnia 17 czerwca 2006.

Tamże.

Tamże.

20 Por. Noch einmal vom Neunten Land. Peter Handke im Gespräch mit Jože Horvat, KlagenfurtSalzburg 1993, s. 66.

21 Tamże, s. 66-67. 


\section{Pożegnanie z dziewiątym krajem}

Stanowisko Handkego w sprawie secesji Słowenii jest ostre i trudno się dziwić, że wywołało burzę. W pierwszym zdaniu eseju Pożegnanie z dziewiątym krajem nie ukrywa swego bezwzględnego stosunku do niej. Według niego podawano wiele różnorodnych powodów dla istnienia samodzielnego, prawnie usankcjonowanego państwa o nazwie „Republika Słowenii”. Jednakże, aby stały się one dla autora możliwe do przyjęcia, musi on je najpierw „zobaczyć”. Rzeczownik „powód” łączy się dla niego nierozłącznie z czasownikiem „widzieć"22. „A ja nie widzę żadnego powodu [...] dla istnienia odrębnego państwa Słowenii, nic poza dokonanym faktem. I tak samo nie widzę powodów dla «Państwa Chorwacji»"23.

„Kraj Słowenia i dwa miliony głów słoweńskiego narodu tymczasem są jedną z tych nielicznych rzeczy, które są nierozłączne z przymiotnikiem "moje”; rzeczy nie mojego posiadania, ale mojego życia"24. Atrakcyjność Słowenii leżała dla Handkego w jej rzekomej „ahistoryczności”, która została przerwana wojną. Poza tym Handke podaje, że widział Słowenię po wszystkie czasy jako integralną część Jugosławii, integralną, ale samodzielną, tak jak inne republiki Federacji Jugosłowiańskiej ${ }^{25}$.

„Ahistoryczność, która może umożliwiała ową obecność pod czystą postacią, była jedynie złudzeniem (jeśli też owocnym?); co najwyżej była to krótka przerwa w historii (lub w naszej nieprzerwanej przymusowości?)"26. Dla pisarza Słowenia od zawsze należała do wielkiej Jugosławii. I właśnie ta oczywista słoweńska samodzielność, jak i samodzielność innych południowosłowiańskich krajów, która wydawało się, że nie będzie wymagała nigdy własnej państwowości - przyczyniała się w jego oczach do rozumiejącej się samej przez się wielkiej jedności ${ }^{27}$.

\section{„Zniekształcone odbicia” versus „świadectwa naoczne" - literacka wizja wydarzeń}

Kolejnym „rozdziałem kontrowersji” było niewątpliwe zaangażowanie pisarza po stronie Serbii w jugosłowiańskiej wojnie. Handke opisuje, dlaczego chciał jechać w „zimową podróż” do Serbii: ${ }^{28}$ „Przede wszystkim ze

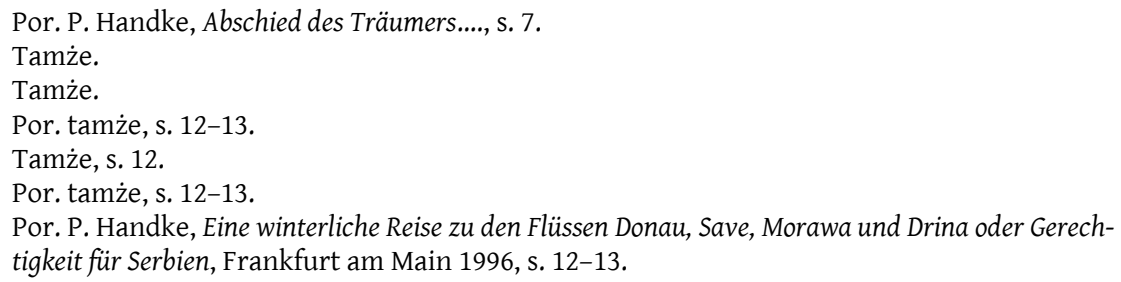


względu na wojnę"- przyznaje Handke. Chciał jechać do Serbii, kraju tzw. "agresorów”. Jednak również sam kraj, jako najmniej znany pisarzowi z całej Jugosławii, zachęcał go do podróży. A może powodem było właśnie to, że wiadomości o kraju - bliżej mu nieznanemu - pojawiały się dzień w dzień na pierwszych stronach gazet. Handke dokonuje podsumowania swoich wrażeń z tego konfliktu słowami: „Prawie wszystkie obrazy i relacje minionych czterech lat dochodziły bowiem tylko $\mathrm{z}$ jednej strony frontów i granic i jeśli nawet międzyczasy pochodziły z drugiej strony, to wydawały mi się one z biegiem czasu coraz bardziej być tylko odbiciami zwyczajnych, rutynowych spojrzeń w bok - spostrzegałem je jako zniekształcone odbicia (Verspiegelungen) w naszych własnych komórkach widzących, a z pewnością nie jako świadectwa naoczne (Augenzeugenschaft)"29.

\section{«Aha, jugofil!»}

Według samego Handkego kierowała nim chęć odkrycia tego, co znajduje się po drugiej stronie krzywego zwierciadła. Każdy artykuł, komentarz, analiza zmuszała go do podróży do Serbii, coraz to bardziej nieodgadnionej. Handke przestrzega od początku swoich przeciwników, którzy - jak się okazało wkrótce - wcale nie myśleli, aby trzymać się tej rady: „Kto teraz pomyśli: «Aha, proserbski!» lub «Aha, jugofil!» [...] ten nie musi czytać w tym momencie nawet dalej". Wypowiadając się w obronie filmu Underground Emira Kusturicy (Bośniaka z Sarajewa), Handke formułuje zarzuty wobec mediów masowych. Według niego gazety nie opisują samego sujetu, nie podejmują także problemów, a tylko podają powierzchowne informacje - przez co stają się one przedmiotami.

\section{To jest film!}

Autor pyta samego siebie, przyjmując pozę dziennikarzy: „Czy ty naprawdę chcesz pomóc odrzeczywistnić serbskie zbrodnie, w Bośni, w Krainie, w Slawonii przez rezygnującą z pierwszej rzeczywistości krytykę mediów? - Powoli. Cierpliwości. Sprawiedliwości" ${ }^{\prime 30}$. Problem, według Handkego, jest znacznie bardziej złożony, związany z większą liczbą stopni rzeczywistości, a jego cel to znalezienie przez odbiorców wspólnej perspektywy. Bowiem co można wywnioskować, widząc jedynie z daleka lub najczęściej w telewizji? Co się wie, gdy przez całe połączenie świata w sieci posiada się tylko wirtualną wiedzę? Nie jest ona tą, którą można zdobyć jedynie przez bezpośrednie patrzenie i naukę. Co wie ten, który zamiast właściwej

29 Tamże, s. 13.

30 Tamże, s. 29. 
rzeczy, ujrzy tylko obraz lub tak jak w wiadomościach telewizyjnych jedynie malutki wycinek obrazu, bądź tak jak w Internecie - wyłącznie wycinek wycinka? ${ }^{31}$

Przemyślenia te ewokują ogólną krytykę medialnej rzeczywistości. Handke formułuje wręcz zbliżone poglądy do zapatrywań francuskiego filozofa Jeana Baudrillarda, według którego rzeczywistość to film z doskonałym scenariuszem. „[T]o, czego jesteśmy świadkami siedząc w naszych fotelach w stanie całkowitego osłupienia, nie jest «jak film» - to jest film. Ze scenopisem i scenariuszem, który należy teraz wyreżyserować, ściśle się go trzymając" 32 .

„A pomimo to, niemal równocześnie z takimi bezprzytomnymi impulsami przemocy uczestnika z oddali patrzącego, druga część we mnie (która jasne, że nie stanowiła nigdy całości) nie chciała tej wojnie i tym relacjom korespondentów wojennych wierzyć. Nie chciała? Nie, nie mogła. Za szybko bowiem dla tak zwanej społeczności światowej również w tej wojnie role atakującego i atakowanego, niewinnych (czystych) ofiar i nagich złoczyńców, zostały ustalone i zapisane na stałe"33.

\section{Wspólne dzieciństwo}

Poza całym szumem medialnym, wręcz narzuca się pytanie, jaki był cel takiego frontalnego ataku pisarza na media? Celem ataku wymierzonego w naczelne europejskie media i polityków, zresztą zupełnie przez drugą stronę zlekceważonego, była pamięć oraz to, co Handke nazywa „wspólnym dzieciństwem". Pisarz bowiem antycypuje zarzuty przeciwników już w eseju Zimowa podróż ${ }^{34}$. Na oskarżenie, czy Handke teraz zaczyna być poetycki, on sam odpowiada: „Tak, jeśli to rozumiemy jako dokładne przeciwieństwo mglistości” ${ }^{35}$. Poetyckość rozumie on jako zobowiązanie, jako całościowe objęcie zagadnienia. Chodzi mu o przyczynek do wspólnej pamięci (wspólnego pamiętania) jako jedynej moźliwości pojednania dla drugiego, wspólnego dzieciństwa ${ }^{36}$. Niewątpliwym błędem Handkego jednak są od początku jego niewybredne nazwy dla dziennikarzy, imiennie atakowanych oraz inwektywy rzucane w kierunku naczelnych mediów Europy Zachodniej, które one

\footnotetext{
Por. tamże, s. 30.

J. Baudrillard, Wirtualność a wydarzenie, w: tenże, Pakt jasności. 0 inteligencji Zła, przeł. S. Królak, Warszawa 2005, s. 103.

P. Handke, Eine winterliche Reise..., s. 38.

Por. tamże, s. 133-134.

Tamże, s. 133.

Por. tamże, s. 133-134.
} 
kompensują następnie w niemniej wybredny sposób, szydząc z tytułów tekstów Handkego oraz odnosząc się nawet do stanu psychicznego pisarza.

\section{Wojna w mediach}

W nową fazę batalia z mediami i polityką wkracza wraz z wojną o Kosowo. Przy czym ,jednostronne przekazywanie faktów, połączone z niedostateczną wiedzą przeciętnego odbiorcy, dotyczącą zarówno historii samego Kosowa, jak i podłoża konfliktu serbsko-albańskiego utrwaliły, w znacznej mierze wypracowany już w czasie wojny w Chorwacji oraz Bośni i Hercegowinie, stereotyp krwiożerczego i prymitywnego Serba, który nie odpowiada standardom proponowanym przez cywilizowaną Europę"37. Edward Białek stwierdza: „Przekonanie o ograniczonej wiarygodności mediów i ich manipulacyjnej mocy skłania go [Handkego - R.M.] w 1999 roku do podjęcia kolejnej podróży na Bałkany. Pisarz chce być naocznym świadkiem wydarzeń nazywanych eufemistycznie «wojną w Kosowie, zamiast wojną przeciwko Jugosławii». Zapiski z owej podróży do bombardowanej przez samoloty NATO Serbii, opublikowane w tomie Unter Tränen fragend (Pytając wśród łez) i stanowiące swoisty dziennik czasu wojny, prezentują wyniki zderzenia z rzeczywistością, która do świadomości Europejczyków i Amerykanów docierała w uproszczonej, bo zniekształconej przez środki masowego przekazu postaci" ${ }^{38}$.

\section{W enklawie bałkańskiej}

Pokładając ufność w teatr jako wolne medium, Handke inscenizuje Przygotowania do nieśmiertelności (Zurüstungen für die Unsterblichkeit. Ein Königsdrama). Nie ulega wątpliwości, że miejscem rozgrywającego się dramatu królewskiego nie jest żadna inna „enklawa” niż Kosowo: „miejsce permanentnego stanu wojennego i nieszczęścia, miejsce «cierpienia ludu od Pola Kosowego po Psie» to bez wątpienia Bałkany z ich nierozwiązanymi do dziś problemami etnicznymi, terytorialnymi i religijnymi" ${ }^{39}$.

Według Edwarda Białka właśnie Przygotowania do nieśmiertelności można odczytać jako ostatni etap, gdzie Handke „przeistoczył się na dobre w pisarza zaangażowanego, który wyrwał się ostatecznie z ciasnoty wieży z kości słoniowej i rajskiej szczęśliwości słoweńskich sadów, by ruszyć przeciwko

\footnotetext{
37 D. Bogdanov oraz S. Giergiel, Wojna $w$ mediach $w$ okresie rozpadu Jugosławii, w: Wojna w mediach, red. B. Nierenberg, W. Piątkowska-Stepaniak, Opole 2007, s. 324-325.

38 E. Białek, Prowokacja wysublimowana. O dramaturgii Petera Handkego, w: tenże, Prowokatorzy i obrońcy ludu: formy zaangażowania w literaturze austriackiej drugiej połowy XX wieku, Wrocław 2002, s. 73-74.

39 Tamże, s. 100.
} 
realnym zagrożeniom wynikającym z faktu powszechnego już dzisiaj «przepychania przestrzeni»" ${ }^{* 0}$. Pewną stałą pozostaje przy tym antyamerykańskie ostrze wypowiedzi protagonistów, które wkłada im w usta sam autor.

\section{Pierwszą ofiarą wojny jest prawda}

Wojna o Kosowo była wyjątkowo medialna. Przyznaje to Susanne Düwell w swoim artykule Ein Toter macht noch keinen Roman (Jeden zabity nie czyni jeszcze powieści). Współcześnie w dziennikarskiej prezentacji wojny najważniejszą rolę odgrywają: wizualizacja wojny oraz jak najszybszy, niemal natychmiastowy przekaz, najlepiej na żywo („live”). Przyspieszenie komunikacji mediów masowych wpływa często na brak w analizie wydarzeń weryfikacji podstawowych informacji, pochodzących częstokroć z niepewnych źródeł. Są one przejmowane przez dziennikarzy od stron uczestniczących w wojnach. Właśnie tu rozpoczyna się krytyka Handkego ${ }^{41}$. Zdaniem powtarzanym częstokroć w czasie wojny pozostaje stwierdzenie, że pierwszą ofiarą wojny jest prawda. Dušan Bogdanov oraz Sabina Giergiel wykazują, że nie mały udział w tym mają same media masowe ${ }^{42}$.

\section{Błądzenie w czółnie - Irrfahrt im Einbaum}

Handkego respons na kontrowersję medialną jest sztuka teatralna Podróż w czótnie albo scenariusz do filmu o wojnie. Już samo motto poświęcone nowemu dramatowi jest znamienne. Nieprzypadkowo pisarz austriacki cytuje autora jugosłowiańskiego Ivo Andrića: „Moralne rozczarowanie błędami innych, które ujawniają nasze własne, zupełnie do tamtych podobne, pozwala nam przyjąć zdecydowaną i szlachetną postawę zarazem sędziów i ofiar, wywołując $\mathrm{w}$ nas stan moralnej euforii. Ta euforia szybko i zdecydowanie odbiera nam szansę jednostkowej, moralnej samorealizacji, zmieniając nas w przerażających i pozbawionych współczucia, wręcz spragnionych krwi sędziów”43. Opis sceny Handke rozpoczyna w didaskaliach: „Scena przedstawia jadalnię dużego prowincjonalnego hotelu, położonego gdzieś w głębi Bałkanów" ${ }^{4}$. Szybko sztuka została ochrzczona przez media „błądzeniem w czółnie" (Irrfahrt im Einbaum).

\footnotetext{
$40 \quad$ Tamże, s. 102.

${ }^{41}$ Por. S. Düwell, Ein Toter macht noch keinen Roman. Repräsentationen des Jugoslawienkrieges bei Peter Handke und Norbert Gstrein, w: Zeichen des Krieges in Literatur, Film und den Medien, ed. Ch. Petersen, Dublin 2006, s. 92-93.

${ }^{42}$ Por. D. Bogdanov, S. Giergiel, Wojna w mediach..., s. 319-328.

43 Cyt za: P. Handke, Podróż w czótnie albo scenariusz do filmu o wojnie, w: tenże, Konno przez Jezioro Bodeńskie. Podróż w czótnie albo scenariusz do filmu o wojnie, przeł. D. i K. Sarajewscy, Kraków 2004, s. 103.

44 Tamże, s. 105.
} 
Charakterystyczne stanowisko dla USA prezentuje amerykański reżyser „filmu o wojnie”, Handke ujmuje to tak: „Kiedy przekraczałem granice tego kraju, nie byłem w stanie powiedzieć, gdzie jestem. Ani śladu po Stanach Zjednoczonych; ani też po Europie - Czy to w ogóle jest «Europa»? «Azja» to chyba też nie jest? Co to jest? - coś, co moim amerykańskim oczom nie mogłoby się nawet przyśnić" ${ }^{45}$. Pisarz krytykuje absolutne niezrozumienie obcych interwenientów w konflikcie, który jest niezwykle złożony.

Postać trzeciego światowca prezentuje podobne stanowisko, które zostaje poszerzone o niewytłumaczalną wrogość, wręcz nienawiść, którą Handke zarzuca mass mediom już od początku konfliktu. "Już wówczas nie wiedziałem, gdzie jestem. To mój ówczesny tłumacz wstawiał nazwy miejscowości w pozostawionych przeze mnie miejscach w artykule. Od początku nienawidziłem tego kraju. $W$ dolinach nie rozpoznawałem dolin, jakie znałem ze swojego kraju, tylko zimne kotliny. A tutejsze rzeki: dla mnie żadna nie zmierzała ku morzu, tylko po prostu płynęła, nie piętrzyła się w kółko, w tysiącach zimnych kotlin pławiła się we własnym sosie. Od początku nienawidziłem też tutejszego narodu, wszystkich, tak jak do wybuchu wojny nienawidziłem co najwyżej samego siebie, bez żadnych wątpliwości, otwarcie, wolny w końcu od nienawiści do samego siebie" ${ }^{46}$.

Handke ponownie odnosi się nieufnie do historii i historyków. Badacz ojczyzny albo miejscowy kronikarz okazują się być tak samo zaangażowani osobiście w konflikt jak wszystkie inne strony konfliktu. „Jako kronikarz powinienem być właściwe niezauważalny - zauważalny tylko w moim dziele. A moje dzieło zauważalne dopiero długo po mojej śmierci. A w tym dziele niezauważalna moja własna ręka - żadnych wyszukanych słów, żadnych esów-floresów. Pełnia życia kronikarzy. Szczyt egzystencji. W każdym razie dla mnie. A teraz wojna wyciągnęła kronikarza na światło dzienne. I ja mam mówić. Ja! Już nawet: «Ja i kronikarz» do siebie nie pasuje. A co dopiero: Kronikarz i mówić!"47.

\section{Nie ma problemu. Nie ma Jugosławii}

Handke szyderczo podsuwa spikerowi obce stanowisko, które mogłoby być rzekomym rozwiązaniem. „Nema problema. Nema Jugoslavije. Nie ma problemu. Nie ma Jugosławii”48. Małgorzata Sugiera podsumowuje: „Handke - mieszkaniec wieży z kości słoniowej z własnego wyboru - w połowie lat dziewięćdziesiątych został dość dla samego siebie nieoczekiwanie wplątany

45 Tamże, s. 107.

46 Tamże, s. 139.

47 Tamże, s. 116-117.

48 Tamże, s. 187. 
w coś, co dotąd zawsze go przerażało - w historię. Od początku jednak ograniczał swoje wypowiedzi do dziedziny mu najbliższej, czyli do krytyki języka i świadomej obłudy tych, którzy się nim posługiwali" ${ }^{\prime 9}$.

\section{Slobo i Heine - proces w sprawie zbrodni w byłej Jugosławii}

Pikanterii kontrowersji sprawy serbskiej dodawały kolejne wystąpienia Handkego. W 2004 roku odwiedził on Slobodana Miloševića w więzieniu w Hadze. Rok później znowu zrobiło się głośno wokół pisarza, gdy obrońcy byłego prezydenta Jugosławii zaprosili Handkego w charakterze świadka do Międzynarodowego Trybunału ds. zbrodni w byłej Jugosławii w procesie o zbrodnie ludobójstwa oraz zbrodnie przeciwko ludzkości. Handke mimo że odrzucił tę propozycję, to niedługi czas później opublikował esej Die Tablas von Daimiel, który ponownie podgrzał atmosferę wokół międzynarodowego już sporu. 18 marca 2006 roku Handke wystąpił z mową na pogrzebie Slobodana Miloševića, co spowodowało ponowne ożywienie kontrowersji. W reakcji na to paryska Comédie Française skreśliła demonstracyjnie ze swojego repertuaru sztukę Das Spiel vom Fragen oder die Reise ins sonore Land. Ostatecznie 2 czerwca 2006 roku Peter Handke zrezygnował z prestiżowej nagrody literackiej Heinricha Heinego miasta Düsseldorf.

\section{Moja opowieść nie jest bajką}

Zupełnie inne stanowisko przedstawia Slavenka Drakulić, sprzeciwiając się tendencji mityzowania wojny w Jugosławii, do której przyczyniał się również Handke. To właśnie austriacki autor wypowiadał się, że zaobserwował pewną niemal mityczną solidarność Serbów w czasie nałożonego na nich embarga przez pozostałe państwa Europy.

Slavenka Drakulić nie mityzuje obrazu Serbii, ale przedstawia w Oni niskrzywdziliby nawet muchy. Zbrodniarze wojenni przed trybunałem w Hadze to, co Maria Todorova opisała w sposób naukowy w Bałkanach wyobrażonych: „W odległym zakątku Europy, za siedmioma górami i siedmioma rzekami, był sobie kiedyś piękny kraj o nazwie Jugosławia. Mieszkali w nim ludzie sześciu różnych narodowości, którzy wyznawali trzy różne religie i mówili czterema różnymi językami. [...] Ale ponieważ moja opowieść nie jest bajką, historia tego pięknego kraju nie ma szczęśliwego zakończenia. [...] Wszystko to wydarzyło się w środku Europy nie tak dawno temu, między 1991 a 1996 ro-

49 M. Sugiera, Więźniowie języka, w: P. Handke, Konno przez jezioro bodeńskie. Podróż w czótnie albo scenariusz do filmu o wojnie, przeł. D. i K. Sarajewscy, Kraków 2004, s. 11. 
kiem. Wojna ta zaskoczyła cały świat. My, obywatele Jugosławii, byliśmy zaskoczeni jeszcze bardziej"50.

\section{Morawska noc - Kosowskie wino}

W Morawskiej nocy (Die morawische Nacht) wydanej w 2008 roku Handke w sposób pośredni dystansuje się od wcześniejszych tez, ale nie może się powstrzymać od przemycenia między wierszami przekazu o słodkiej nucie wysublimowanej ironii. Były już pisarz (Ex-autor) do picia proponuje wina, które - po przejęciu przez francuskich, austriackich oraz kalifornijskich właścicieli - zachowały swoje dawne nazwy z ziemi nad Morawą: Szmaragd, Rubin, Melancholia - jak i również wino o wdzięcznej nazwie „Kosowe pole"51. Oczywista jest tutaj aluzja do bitwy na Kosowym Polu, która konstytuuje przecież świadomość narodową Serbów.

I ponownie pojawia się „enklawa”. "Jako enklawę widział on swoją stanicę wodną, jako samemu proklamowaną eksterytorialność? Czy nie chciał on zrozumieć, że w tym czasie już dawno nie mogło być enklaw? Że coś takiego a wraz z tym wszelkie «myślenie w kategorii enklaw» (Enklavendenken) było «naganne»?"52

Zdaje się, że w dzisiejszych dniach po ogłoszeniu niepodległości Kosowa (niedawno minęła już pierwsza rocznica) wypowiedzi Handkego zyskują ponownie nowy wymiar. Aż po ostatnie dni odnosi się on do niezmiernie aktualnej tematyki bałkańskiej. W pełnej ciekawości oczekujemy nowego odzewu pisarza: razem z czytelnikiem zobaczymy zatem, co przyniesie przyszłość.

R A F A $€ \quad$ M I C H A L C Z U K

50 S. Drakulić, Oni nie skrzywdziliby nawet muchy. Zbrodniarze wojenni przed trybunałem w Hadze, przeł. J. Szacki, Warszawa 2006, s. 7.

51 Por. P. Handke, Die morawische Nacht, Frankfurt am Main 2008, s. 26-27.

52 Tamże, s. 35. 


\section{Abstract}

Peter Handke (born 1942, in Griffen, Austria) is an avant-garde Austrian novelist and playwright. He gained popular attention after a spectacular appearance at a meeting of avant-garde artists belonging to Gruppe 47 in Princeton, where he presented his play Offending the Audience (Publikumsbeschimpfung).

When he published his travelogue A Journey to the Rivers: Justice for Serbia (Eine winterliche Reise zu den Flüssen Donau, Save, Morawa und Drina oder Gerechtigkeit für Serbien) in 1996, Peter Handke created a considerable controversy, which started his long battle against literature, politics and mass media. Gradually Handke became a "political writer" who defended his point of view of Yugoslavia's state-collapse. Handke, connected since his birth with region Carinthia in Austria and his "mental ancestors", Carinthian Slovenes, first criticized the secession of Slovenia from Yugoslavia in his essay The Dreamer's Farewell to the Ninth Country (Abschied des Träumers vom Neunten Land) and afterwards openly attacked Western media for misrepresenting the causes and consequences of the Balkan War.

In his plays Preparations for Immortality. A Royal Drama (Zurüstungen für die Unsterblichkeit. Königsdrama) and The Canoe Ride or The Play about the Film about the War (Die Fahrt im Einbaum oder Das Stück zum Film vom Krieg) he took a step further and engaged in a long polemic against the US-inspired intervention in Kosovo.

Furthermore, in 2006 Handke resigned from receiving the Heinrich Heine Prize in literature and gave a speech in Serbian at the funeral of Slobodan Milošević, which sparked much controversy in the West of Europe.

The article The long farewell from Yugoslavia deals with the literary and political aspects of the controversy created by the Austrian writer and especially the reaction of mass media against Handke's "political engagement" in the conflict in the Balkans. 